University for Business and Technology in Kosovo

UBT Knowledge Center

UBT International Conference

2016 UBT International Conference

Oct 28th, 9:00 AM - Oct 30th, 5:00 PM

\title{
Foreign Direct Investment (FDI) Types and Theories: The Significance of Human Capital
}

\author{
Nazmi Zeqiri \\ University for Business and Technology, nazmizeqiri@hotmail.com \\ Hykmete Bajrami \\ University of Prishtina, hykmetebajrami@gmail.com
}

Follow this and additional works at: https://knowledgecenter.ubt-uni.net/conference

Part of the Business Commons

\section{Recommended Citation}

Zeqiri, Nazmi and Bajrami, Hykmete, "Foreign Direct Investment (FDI) Types and Theories: The Significance of Human Capital" (2016). UBT International Conference. 23.

https://knowledgecenter.ubt-uni.net/conference/2016/all-events/23

This Event is brought to you for free and open access by the Publication and Journals at UBT Knowledge Center. It has been accepted for inclusion in UBT International Conference by an authorized administrator of UBT Knowledge Center. For more information, please contact knowledge.center@ubt-uni.net. 
Book of Proceedings

International Conference on Management, Business and Economics

\title{
Foreign Direct Investment (FDI) Types and Theories: The Significance of Human Capital
}

\author{
Nazmi Zeqiri, Hykmete Bajrami \\ UBT - Higher Education Institution, Lagjja Kalabria, 10000 p.n., \\ Prishtine, Kosovo \\ University of Prishtina, Economic Faculty \\ Marketing Department \\ nazmizeqiri@ hotmail.com, hykmetebajrami@gmail.com
}

\begin{abstract}
One of the economic problems of undeveloped countries, and Kosovo, is that they do not have enough national savings to finance their investments. They are in constant need of foreign capital in forms of both direct and indirect investments, but not every country is able to attract the right mode of FDI, nor does every investor risks his investments without studying the conditions in the host country. The practice of FDI attraction generally incorporates numerous fiscal and monetary incentives. However, one should note that FDI attraction should be accompanied by development and an increase in the level of human capital, as a prerequisite to attract the right FDI and not every kind of foreign investment.

FDI, together with human capital development, are considered among the key drivers of growth as they play complementary effects and reinforce each other. The role of human capital in stimulating FDI and vice versa is one of the controversial issues in the development literature.

Human capital is the factor where the transition process has had significant and long-term implications. Human capital bacame a crucial determinant and a prerequisite for FDI attraction that a country, including Kosovo, must have if willing to attract the right mode of foreign capital.

This paper seeks to understand the weight of human capital in different types and theories of FDI. Theory and empirical studies are inconclusive as per direct impacts of FDI in developed countries, but when it comes to transition and undeveloped economies, and Kosovo, there is more agreement on the positive effects of FDI in economic development and human capital.
\end{abstract}

Key words: FDI, human capital, transition, theories

\section{Introduction}

The transition process from communism-central planning, to capitalism-open economy, in most of the transition countries has gone through structural and dramatic changes. Domestic capital, in most of these transition countries and Kosovo, was incapable to meet huge investment needs that transition required. In the early stages of the transition process, the importance of Foreign Direct Investments (FDI) is seen as crucial and a top priority for policy makers. In general, the practice of FDI attraction usually incorporated numerous fiscal and monetary incentives. However, one should note that FDI 
Foreign Direct Investment (FDI) Types and Theories: The Significance of Human Capital

attraction should be (apart from monetary and fiscal incentives) accompanied by development and an increase in the level of human capital, as a prerequisite to attract the right FDI and not every kind of foreign investment - something that happened in Kosovo. Determining which kind of foreign investments a country will attract is a very important step in terms of development and orientation of available human capital stock. Because of structural problems with human capital, Kosovo and other countries that have high unemployment sometimes attempt to attract every kind of FDI, even if it proves to be of limited help, but decreases high unemployment. Such investments (rent seekers) are not necessarily long term oriented and do not create long-term employment and sustainable development of human capital. Moreover, according to Hoti (2005), these investments, in short term, also push wage inequality hence placing strong pressure on the public sector for wage increases (Hoti, 2005).

In the beginning of transition from communism to capitalism, many researchers argued that the average level of education embodied in human capital within transition economies was relatively high (Duczynski, 2001; Druska et al., 2002, Spagat, 2006). However, later on, a number of researchers and empirical studies from well-known international institutions suggested that transition economies lag behind compared with industrialized countries in terms of the quality of their workforce (EBRD 2008). One of them is a supply of trained and educated human capital (UNDP 2010). Since attracting FDI has prerequisites, no doubt, such situation acted as a big barrier to attract higher and qualitative FDI in these countries. Because of this, in the case of Kosovo, which is heavily populated by young people and high unemployment, it is very important to make strong bridges between education and economic development, hence FDI attraction.

As stated earlier, and according to the literature, the problem of human capital was not predicted in the earliest years of transition. When transition started, some researchers argued that the level of human capital in transition countries was quite high, and it did not pose a problem for these countries. The opinion was grounded on simplified proxy by comparing enrollment rates in educational institutions in transition countries to those in the developed countries. In this instance, Spagat (2001 \& 2006) shows that based on the educational levels one might suppose that transition economies are in great shape in terms of human capital. However, later it was realized that skills, knowledge and education that exist might not be relevant for foreign investors from industrialized countries. A report by EBRD (2000), and confirmed also in 2008, stated that companies in transition economies lag behind those in advanced industrialized countries in terms of the quality of their workforce. Many skilled workers are performing jobs that do not reflect their level of education, and over time their ability to perform high-level tasks will diminish. A starting point is the study by Druska et al. (2001), who confirmed the problem of human capital in transition countries. In their study, Druska et al (2001) showed that there is a significant mismatch between the type of skills and competencies that the new economy demands and foreign investors and the types of skills and competencies that workers possess. As a consequence, the mismatch between the huge stock of human capital (the supply) and the necessary skills required (the demand) from foreign companies is thought to be a barrier to attract FDI, especially foreign investors that need specialized and trained human capital for their operations in host country. This phenomenon was emphasized more for transition countries that entered very late into the transition process, and FDI was seen as an important injection to boost investment capacities. More specifically, Talpos \& Enache (2010) argue that FDI inflows in Central and Eastern Europe (CEE) "have specific patterns of human capital, different from the ones specific to the rest of the developing countries" (p.487).

Having said this, one can conclude that human capital matters in attracting FDI inflows and can speed up the transfer of know-how from foreign investor to host country. The importance of human capital in economic development is widely accepted nowadays. It has been shown that the aim of development 
is the human being who is at the same time the actor and the beneficiary of development (Fongang, 2006). For a new country such as Kosovo, the human capital development and FDI inflows are considered equally vital factors for future economic development. There are many reasons why Kosovo desperately needs higher inflows of foreign capital and availability of qualitative human capital. Kosovo currently lacks the domestic capital that is needed to fulfill huge domestic needs and is faced with high unemployment.

\section{Literature review}

This part, targets, and discusses the main theoretical aspects of existing literature review pertaining to FDI and human capital relationship. It begins by defining FDI from different perspectives, approaches, authors and institutions toward some common fundamentals that are present in all definitions of FDI hence leading to the discussions of the main types and modes of FDI relative to the role of human capital.

Defining and measuring the impact of FDI is not an easy step to be undertaken, especially when the literature on FDI is massive, but inconclusive in many crucial aspects of FDI. Nowadays, the flow of capital might be intangible, short-term but decisive, not always measurable but rather virtual and complex. Moreover, the literature on FDI also recognizes the challenge that explaining FDI in transition countries is easier said than done. FDI behavior, modes and forecasts are different in developed and democratic countries compared to transition countries (including Kosovo) which are not only imperfect but rudimentary too. According to Vasyechko (2012), "the literature review has shown that besides well-known traditional determinants, drawn from the theory, some transition-specific factors have an unambiguous general impact on FDI patterns in these countries" (p.119).

In general, FDI is the course of action whereby residents or companies of one country-source country (sometimes referred as 'home country') acquire ownership of assets for the purpose of controlling the production, distribution and other activities of a company in another country-host country (sometimes referred 'foreign country'). Economically, FDI is a mechanism to transfer resources, including financial capital as well as technology and human resources across national borders while keeping it under the control of the parent company. FDI definition takes on different meanings depending whether it is seen from the perspective of the foreign investor or the host country. However, according to Moosa (2002) "there is something in common in both perspectives: a) there is a control through substantial equity shareholding; and b) there is a shift of part of the company's assets, production or sales to the host country" (p.2).

According to the International Monetary Fund's Balance of Payments Manual (IMF, 2011) "FDI is an investment that is made to acquire a lasting interest in a company operating in an economy other that of the investor, the investor's purpose being to have an effective voice in management of the company" (p.7). Almost the same definition is found in United Nations Conference on Trade and Development World Investment Report (UNCTAD, 2011) which defines "FDI as an investment that involves a long term relationship and reflecting lasting interest and control of a resident entity in one economy (foreign direct investor or parent company) in a company resident in an economy other that of foreign investor" (UNCTAD, 2011). 
Foreign Direct Investment (FDI) Types and Theories: The Significance of Human Capital

The rationale behind these two credible international institutions who used 'long term' and 'lasting interest' in their definition is to make a distinction between FDI and portfolio investments which are characterized with a lack of long term commitment of foreign investor and involve high turnover of securities. Even the most recent and contemporary literature on the most widely accepted definition of FDI is known as "IMF/OECD benchmark definition" because it was provided by the joint workforce of these two international organizations with the objective of providing standards to national statistical offices for compiling FDI statistics. The gist behind the IMF/OECD benchmark definition is that "FDI is an international venture in which an investor residing in the home economy acquires a long-term "influence" in the management of an affiliate firm in the host economy" (OECD 2008, p.61).

Current FDI trends have not changed much about the mature definition of FDI. For example, a recent book by Theodore Moran (2012) declares the same opinion that FDI takes place "when a corporation in one country establishes a business operation in another country, through setting up a new whollyowned affiliate, or acquiring a local company, or forming a joint venture in the host economy (p.3).

Other FDI definitions that are debated in similar terms include "control" and "lasting interest." In this line Ragazzi (1973), describes FDI commitment "as the amount invested by residents of a country in a foreign company over which they have effective control" (p.471). Contessi and Weinberger (2009) following the IMF/OECD common definition postulates the existence of such long-term control and influence "should be assumed when voting shares or rights controlled by the multinational firm amount to at least 10 percent of total voting shares of rights of the foreign firm" (p.63).

However, one must note that shareholding or voting shares is not the only circumstance to exercise control. According to Lall and Streeten (1977) and Contessi et al (2009), it is not necessary to be the majority shareholder in order to exercise direct control as this can be achieved and exercised even with low equity share or even without an explicit management contract (Lall and Streeten, 1977; Contessi et al 2009). For example, according to actual legislation in Kosovo, an investment is considered foreign only if a foreign entity (or group of foreign entities - in the same company) holds 25 percent of total shares (Law nr. 02/L-33 on foreign investment, p.108).

In the abovementioned definitions, the role and impact of human capital is essential but relative to the mode of investment, location, industry and long-term goals of investors. In some cases, the magnitude of human capital is the central and influential determinant of the decision making process on the location choice of the foreign investor. The relative importance of human capital, however, is not as straightforward as it might appear. The availability of cheap human capital sometimes is not a sufficient condition in the later stages of FDI attraction. For example, cheap and huge availability of human capital might be an advantage for foreign investors and host country in the stage of attraction; but in long term it might become a significant barrier accompanied with policy implications for the host country in increasing FDI in high technology industries or automation of some industries. This is especially so in those cases where the main goal of FDI is no longer to decrease unemployment but instead to increase human capital productivity.

The impact of human capital on FDI and vice versa is surprisingly wide range, inconclusive and differs in least developed countries, developing, developed and transition countries. Theoretical literature, in general, presumes human capital among the most important ingredients of inflow of FDI (Agarwal 1980; Dunning 1988; Lucas 1990; Zhang 1999; Markusen 1999; Aavik \& Walsh, 2010 and Rizvanolli 2010). The role of human capital is not much related to the definition of FDI, but more so with operations, competencies, productivity, spillover effects of foreign investment operating in a host 
Book of Proceedings

International Conference on Management, Business and Economics

country. The results reported from different studies differ in respect to their measures and proxies used, estimation methods, specifications and period covered. According to Bačić, Račić and Šonje (2004), "FDI can facilitate growth of recipient country via capital formation channel directly and via positive spillovers and inclusion into international productive and innovate networks indirectly" (p.59).

Moreover, Zhang and Markusen (1997) in their empirical study found that the poorest countries attract less foreign investment share of world FDI than their share income. In the same study, the researchers found that small markets attract fewer investments per capita when compared to big markets. Their models also suggest the existence of a development trap for small, skilled-labor-scarce countries (p.1920). In this line, Kucera (2002) in his cross-section analysis found a positive impact of net average FDI on human capital (proxies: literacy rates, and average years of education for population over 15 years old) during the period of 1993-1999. Another study to find positive correlation between human capital and FDI inflow is the study undertaken by Shatz (2003) in 100 developing countries. The study used only one proxy; years of education for people over 15-year-old and over. The results from the study conclude that FDI is positively impacted by human capital (Shatz, 2003).

The correlation between human capital and FDI is found also in a study of Teixeira (2005). His study concludes that foreign capital positively affects human capital in the education and specific skills needed to perform a job. Moreover, the same study points out that research and development (R\&D) has a significant mediating role in that positive correlation between FDI and human capital intensity (Teixeira, 2005).

\section{Types of FDI: the significance of human capital}

Depending from which perspective is studied and other specific purposes, researchers distinguish different types of FDI. In a broader sense, and for the purpose of this study, the major classifications are: 1) Greenfield Investments; 2) Mergers and Acquisitions (M\&A); and 3) Joint Ventures.

\subsection{Greenfield investments}

Greenfield investments are made when foreign companies expand the bulk of investment or establish new production capacities in the host country. Greenfield investments are a most welcomed foreign investment for host countries, especially when the main goal is to decrease high unemployment. Greenfield investments are the primary target of a host nation's promotional efforts because they create new production capacity, jobs, transfer technology and know-how, and can lead to linkages to the global marketplace. In terms of human capital greenfield FDI usually creates new jobs and increases the productivity. Though greenfield investments are welcomed in the host country, one should note that this might crowd out local companies and some specific industries (particularly those dependent upon technology). While the profit of local companies flows back into the domestic market, this is not always the case with foreign companies that undertake greenfield investments. Because of high unemployment, in case of Kosovo, this type of FDI or similar sub-types are most welcomed. 
Foreign Direct Investment (FDI) Types and Theories: The Significance of Human Capital

\subsection{Mergers and acquisitions}

Mergers and acquisitions (M\&A) usually are undertaken when a transfer of existing assets from local firms to foreign firms takes place. In other words, assets and operation of firms from different countries are combined to establish a new legal entity. It is assumed that in countries with lower levels of development there are fewer opportunities for M\&A behavior that exist. According to IPAK (2012) Annual Study on Perception of FDI, compared to greenfield investment "M\&A provide no long term benefits to the local economy, because in most deals the owners of the local firm are paid in stock from the acquiring firm, meaning that the money from the sale could never reach the local economy" (p.9). The most emphasized benefit from this type of FDI is increased productivity of the workforce, but not much can be proved in terms of increased employment. Empirical studies in this line are inconclusive and contradictory.

\subsection{Joint ventures}

Joint ventures can involve a local company, government or a foreign company operating in the host country. Cross-border joint venture is one in which economic entities from at least two countries are involved. One positive spillover in terms of human capital is technical spillover especially when there is a combination of foreign and local company. According to Dunning and Lundan (2008), one of the main factors "influencing the viability and success of cross-border joint ventures concerns the choice of partner and reciprocal trust between partners" (p.273). Rather than profit gain, there are different factors and motives behind joint ventures. According to the model of Casson (2000), formation of joint ventures has nine factors such as: economies of scale, market size, economies of scope, technological uncertainty, technological change, cultural difference, interest rates, protection of autonomy and missing patent rights (Casson, 2000). The significance of human capital development in joint ventures varies in developed countries compared to transition and undevelopment countries.

\section{FDI theories and hypothesis: the significance of human capital}

Historically, the first attempt to explain international trade and FDI was considered Ricardo's theory of comparative advantages (Denisia, 2010). Though realistic, one should note that FDI cannot be explained by a theory that is based only in two countries, two products and perfect mobility of resources. Recently, capital flow, international trade and FDI marked an enormous increase. The choice of FDI depends on preliminary analyses, factor analyses and long-term objectives of the investors.

Numerous theories and hypothesis are used to separate FDI from international trade theory. To clarify the terminology, we use term 'general FDI theory' to encompass all the mainstream theoretical variety on the issue. In this line, theories and hypothesis seeking to explain the motivations behind FDI are related with MNCs' choice of particular entry modes and localizations. Several studies provide overviews of FDI theories: for example, Agarwal (1980); Calvet (1981); Helleiner (1989); Cantwell (1991); Meyer (1998); Markusen (2002) and more recently, Faeth (2009) and Denisia (2010). Overall, in particular based on a classification proposed by Faeth (2009), there are 12 main branches of FDI theory:

1) Monopolistic advantage theory, (Hymer, 1960; Vernon, 1966) 
Book of Proceedings

International Conference on Management, Business and Economics

2) Aggregate variables as determinants of FDI (Scaperlanda and Mauer, 1969)

3) The substitute theory (Mundell, 1968),

4) The complement theory (Kojima, 1975),

5) OLI paradigm (Dunning, 1981),

6) The theory of traditional multinational activity determinants of horizontal FDI according to the proximity-concentration hypothesis and vertical FDI according to the factor-proportions hypothesis (Markusen, 1984; Helpman, 1984),

7) The theory of horizontal FDI, vertical FDI and the knowledge capital model (Markusen, 1996, 1997; Markusen and Venables, 1998),

8) The resource-based theory (Wernerfelt, 1984; Barney, 1991),

9) The business network theory (Jarillo, 1988; Ebers and Jarillo, 1998),

10) Theory of new economic geography (Krugman, 1995),

11) Diversified FDI and risk diversification model (Rugman, 1975, 1976; Kopits, 1979; Miller and Pras, 1980), and

12) Policy variables as determinants of FDI (Bond and Samuelson, 1986; Black and Hoyt, 1989; Haufler and Wooton, 1999; Haaland and Wooton, 1999).

Another approach of studying FDI theories is by classifying all theories under two headings: $i$ ) from macroeconomic point of view, FDI is a "particular form of capital flows across borders, from countries of origin to host countries, which are found in the balance of payments. The variable of interest is: capital flows and stocks, revenues obtained from investments" (Denisia 2010); and ii) from microeconomic point of view that tries to put forward the main motivations of foreign investors (Lipsey, 2001). It also examines the "consequences to investors, to the country of origin and to the host country, of the operations of the multinationals rather than investment flows and stock" (Denisia 2010, p.54)

Even the newest theories on FDI cannot capture entire complexity of FDI, and other forms of foreign investments, thereby, are difficult to find a general framework, approach or theory that is accepted and explains everything about FDI and some classifications of FDI theories may result in some overlap (Agarwal 1980; Lizondo 1991; Dunning 2008; Vasyechko 2012).

Despite numerous classifications of FDI theories, for our purposes, the standard classification and approach employed by the author is the one followed by Agarwal (1980), discussed and analyzed in Moosa (2000) and Denisia (2010) that splits most FDI theories into two categories: 1) Theories assuming perfect markets; 2) Theories assuming imperfect markets

\subsection{Theories assuming perfect markets}

The most important theories and hypothesis that assume perfect markets are: a) the differential rates of return theory and hypothesis; b) the portfolio diversification theory and hypothesis; and 3) the market size theory and hypothesis

\subsubsection{The differential rates of return theory and hypothesis.}

The theory of differential rates of return is among the oldest theories that attempts to clarify why some companies run after new markets or indulge in FDI. The main idea and hypothesis of this theory is that capital flows from countries with low rates of return towards countries with higher rates of return. "The 
Foreign Direct Investment (FDI) Types and Theories: The Significance of Human Capital

rationale for this hypothesis is that companies considering FDI behave in such a way as to equate the marginal return on and the marginal cost of capital" (Moosa 2002, p.24). It is obvious that this theory assumes risk neutrality hence making the rate of return alone as main determinant why a foreign investor selected a specific location or mode of investment. Based on this assumption, domestic and foreign investments are perfect substitutes.

In this respect, some empirical studies tried to examine the correlation between relative rates of return in a number of countries and the allocation of FDI among them, but failed to provide supporting evidence (Agarwal, 1980). Among influential studies testing such hypothesis is that of Weintraub (1967), who used US data to test main hypothesis of this theory. The conclusion was that "there was no significant relationship between inter-country differences in the rate of return and the flow of capital" (Weintraub, 1967). In addition, the studies by Bandera (1968) and White 1986) also rejected the main hypothesis of this theory. However, an important step in their studies is the recognition of sufficiency of return as a prerequisite for the movement of capital (Bandera, 1968; White 1986).

An observed problem and consistency of the main hypothesis of this theory is that countries simultaneously experience inflow and outflow of FDI. If the main hypothesis of this theory is that capital flows from countries with low rates of returns toward countries with higher rates of returns, then it will flow in one direction - only toward countries with higher returns and not vice-versa, which is not a consistent with current situation in international trade, FDI stock and location.

In terms of human capital, a very interesting study is that of Barrel and Holland (2000). In their study, they found that FDI has led to increasing labor productivity, hence, to higher rates of returns in the manufacturing sector in Central Europe (CE), especially in cases when capital moved from developed to undeveloped countries. Another interesting research study was that of Yang (1999), who tried "to adjust the rates of return on physical capital to allow for differences in human capital as an explanation for why FDI may go low return countries. The study tried to explain why the majority of FDI in China has been flowing to rich coastal areas rather than to poor inland areas, when rates of return are higher in poor areas.

\subsubsection{The portfolio diversification theory and hypothesis}

The unique theoretical background of this theory can be traced back to the theory of portfolio selection of Tobin (1958) and Markowitz (1959). The impact of this theory is observed in increasing international trade and capital mobility. In contrast to the differential rates of rate of return theory, here risk is an essential determinant. According to Moosa (2002) "capital mobility and FDI will be constrained by the desire to minimize or reduce the risk, which is achieved by diversification" (p.26). In the case of transition countries, including Kosovo, this theory is very helpful to explain some behavior patterns of FDI decisions and risk associated with such investments.

There are numerous ways to test the relationship between the amount of FDI and risk existence in a particular areas or a group of countries. As discussed in Moosa (2002), documented by Haufbauer (1975) and Agarwal (1980), and later by Denisia (2010) "One way to test this hypothesis is to examine the relationship between the share of FDI going to a group of countries and two decision variables: the rate of return, and risk as measured by the variance or the standard deviation of the rate of the return" (p.26). 
Book of Proceedings

International Conference on Management, Business and Economics

Like the differential rates of return theory, the portfolio and diversification theory does not explain why MNCs are the greatest contributors to FDI, and why they prefer FDI to portfolio investment. In this respect, a good explanation is given by Ragazzi (1973) that might be true also in the case of Kosovo. According to him, in the case of developing countries, financial markets are not only imperfect but also rudimentary, hence making portfolio investment less attractive than FDI (Ragazzi, 1973). Another reason might be also the degree of control. MNCs prefer FDI compared to portfolio investment because it gives more control over the assets and other financial means in the host country. In terms of human capital, most of the studies are inconclusive and derived from country specifications.

\subsubsection{The market size theory and hypothesis.}

The market size theory and hypothesis explains the volume and directions of FDI in light of the market size of the host country. According to this theory, large market size is expected to have a positive impact on FDI. The market size hypothesis argues that "inward FDI is a function of the size of the host country market, usually measured by GDP” (Majeed and Ahmad 2008, p.79).

A majority of the empirical studies on the determinants of FDI, in one way or another, contain some measures of market size in the host countries, typically using real GDP comparing to nominal GDP as a proxy (Moore 1993; Bajo-Rubio 1994; Sosvillo and Rivero 1994; Wang and Swain 1995; Lipsey 2000; Love \& Lage Hidaldo; Bogdanova and Olovska 2008; Dunning 2008; Contessi and Weinberger 2009). These studies used either real GDP or nominal GDP as a proxy to determine the significance in attracting FDI.

Should this be true, then Kosovo, which has small market size and GDP, will find that efforts to attract FDI are not productive. But, this conflicts with apparent "real life" results since Kosovo is a net importer of goods and services. However, some studies did not find this relationship. For example, studies by Groenewold (2000); Tcha (2000) and Yang (2010).

\subsection{Theories assuming imperfect markets.}

There are many FDI theories that assume imperfect markets. These section discuses the following theories and hypothesis: a) he location theory and hypothesis; b) the internalization theory and hypothesis; c) the eclectic theory or OLI paradigm and hypothesis; c) the international product life cycle theory and hypothesis

\subsubsection{The location theory and hypothesis.}

The main idea of this theory is mobility of some factors of production, such as labor and natural resources. According to this theory and hypothesis, FDI exists because of mobility of some factors of production hence such mobility leads to location-related differences in the cost of factors of production.

One of the most important elements that can impact location related differences is human capital accounted for in terms of wages paid by foreign investors. In terms of human capital, the location hypothesis attempts to argue that countries with low relative wages are a preferred destination for FDI. However, what matters, is not just the wage but also the quality and productivity of workforce that foreign investors rank very high. 
Foreign Direct Investment (FDI) Types and Theories: The Significance of Human Capital

Another important element for foreign investors as to selecting a specific location is the cost of the reallocation and adjustment of resources. When these costs are high, they lower the possibilities to attract foreign investors (though some researchers argue that reallocation and adjustment costs are very small and not decisive factor). Such conclusions were reached by Porto and Hoekman, (2010) and Francois et al (2011), but there have been some notable exceptions too (e.g. Cosar, 2011). Exceptions are found also in a model developed by Susan Stone, Patricia Sourdin and Clarisse Legendre (2013) postulating that "while it is widely accepted that there are adjustment costs associated with reallocation of resources, in most models these costs are assumed to be very small, more recent evidence is casting doubt on this assumption" (p.2).

In terms of human capital, the location hypothesis also emphasizes the degree of unionization by workers' representatives in the host country, because is assumed that unionized and centralized trade unions have higher bargaining power thereby pushing future wages higher. Nowadays, involvement of MNCs in FDI would prefer flexible and non-unionized labor markets in preference to centralized and unionized. This hypothesis is supported by Leahy and Montagna (2000), who show "that in absence of taxes and other subsidies, the MNC is less likely to locate in the host country under decentralized than under centralized wage setting regime, despite the fact that latter typically yields higher wages" (p.245).

\subsubsection{The internalization theory and hypothesis.}

The first attempts to explain the internalization theory in a national context was made by Coase (1937), then developed by Buckley and Casson $(1976 ; 1983)$ and Hennart (1982). Narrowed focus only in national context was improved when Hymer (1976) developed the theory also in an international context. Sometimes this theory is claimed to represent a general theory of FDI and other theories are a subset of the general theory of internalization hypothesis. According to this theory, certain costs can be saved by internalization of some processes. Denisia (2010) argues that internalization theory also "provides an explanation of growth of MNCs and gives insights into the reasons for foreign direct investment" (p.55).

The main hypothesis of this theory is that FDI arises from the efforts by companies to replace market transactions with internal transactions. In the context of FDI, Denisia (2010) identified two major determinants that are crucial when explaining this theory. These determinants are: a) removal of competition; and b) advantages which some companies possess in particular activity (p.56). Through these determinants, internalization theory demonstrates that MNCs "are organizing their internal activities so as to develop specific advantages, which then to be exploited" (Denisia 2010, p.56).

Due to market imperfections, this theory is superior in explaining firm-specific advantages and demonstrates that companies are conditionally involved in FDI. According to the theory, companies will undertake FDI only if the benefits of exploiting firm-specific advantages are higher than the relative costs of the operations abroad.

Eden and Miller (2004) argue that the theory should take into consideration information costs too. They discussed information costs for foreign companies with respect to local companies, currency risk, and different government treatment thereby adjustments costs when investments are made abroad. The theory recognizes the fact that FDI is a firm level strategy decision rather than a capital market financial decision. 


\section{Book of Proceedings}

International Conference on Management, Business and Economics

The importance of this theory in terms of human capital is the emphasis on R\&D that companies must involve in order to survive in new markets hence development and spillover effects on human capital.

\subsubsection{The eclectic theory or the OLI paradigm hypothesis.}

This theory was proposed and developed by John H. Dunning (1977, 1979, 1988 \& 2008). The main idea of eclectic theory is integration of internalization theory, industrial organization theory and location theory into one general framework. According to Dunning (2008), "the eclectic paradigm seeks to offer a general framework for determining the extent and patterns of both foreign owned productions undertaken by country's own companies, and that of domestic production owned and controlled by foreign investors" (p.95).

Eclectic theory is referred to as the "OLI paradigm," which attempts to explain the international flows and FDI in terms of what is the motive rather than what should be the level and the structure of foreign investment. The OLI paradigm includes both macroeconomic location advantages and microeconomic ownership advantages, as they are incomplete if taken separately (Straker, 2006). In addition, the OLI paradigm confirms and develops previous assumptions that apart from the structure of resources and market size, "government policy can also determine the location of FDI in a host country, also taking into account human nature as a motivation of MNCs for FDI" (Vasyechko 2012, p.130). In other words, it addresses itself primarily to positive rather than normative issues. According to Dunning (2008) "it prescribes a conceptual framework for explaining 'what is' rather than 'what should be', the level and structure of the foreign value activities of enterprises" (p.95). Eclectic theory and its framework is based on three advantages: Ownership $(O)$; Location $(L)$ and Internalization $(I)$.

According to eclectic theory, "ownership $(O)$ advantage" explains the "why" or motivation, of MNCs activities. Dunning (2008) postulates that "ownership advantages are defined as the degree to which a firm possesses sustainable ownership-specific advantages over other firms in the market. Some examples of these advantages are: innovative capacity, access to financial resources, and organizational and marketing systems" (p.96). This includes all the specific, often intangible assets, which a company can either create (through managerial and organizational skills and knowledge,) or purchase (e.g. brand names, patents, etc) compared to local competitors that do not posses.

Another important advantage of eclectic theory is "location $(L)$ advantage" that explains the "where," or location of the companies and which are specific to the country. Examples of such specifics are: labor force (availability and quality), natural resources and societal structure (political structure and legal systems) as explained above under the heading of location theory and hypothesis. The logical consequence will be that company will supply the foreign market from home country base, but location advantage such as distributions of inputs makes it profitable for a company to exploit its assets overseas.

Finally, internalization (I) advantage explains the "how," or the manner, of MNCs activities. Internalization" is the degree of ownership and control. At one end of the spectrum is no control or ownership. Transactions are made at arm's length or through the market. At the other end of the spectrum is full control. The firm "internalizes" the market transactions by owning or controlling the other firm and the transactions are not arm's-length" (Dunning 2008, p.327-330). The more ownership specific advantages a company has compared to competitors the higher is the incentive to internalize their use. Details of this specific advantage are discussed and explained under the heading of internalization theory and hypothesis. 
Foreign Direct Investment (FDI) Types and Theories: The Significance of Human Capital

\subsubsection{The international product life cycle theory and hypothesis.}

The international life cycle theory started to take hold after World War II in viewing the international production as a sequential process. The theory was developed by Raymond Vernon (1966) who combined micro theory of the product cycle with trade theory. Vernon believes that there are "four stages of production cycle: innovation, growth, maturity and decline" (Denisia 2010, p.55).

In this respect Vernon (1966) explained his arguments by stating "that in the early stages of the life of a product, production is undertaken in the home country because of the need of producers to have easy access to inputs and to maintain swift communication with suppliers and competitors. At this stage, the product is highly differentiated and its demand fairly inelastic" (p.195). Producers later begin to export the product to advanced countries, which have demand and supply characteristics similar to those of home country. Petrochilos (1979) and Denisia (2010) find such hypotheses useful and central for interpretation of FDI too though recognize the fact that such hypothesis are referential particularly for products and services that are highly technological and related with income elasticity of demand.

Moreover, according to this theory and hypothesis, the importance of human capital is essential in the decision to establish production in the host country. Vernon (1979) postulated "that in the advanced stages of standardization, labor costs will become a critical consideration in production, hence less developed countries with low-cost labor will now offer a competitive advantage as a production location" (p.6).

Three stages of the products are central in explanation of this theory: 1) the initial production that takes place from innovating companies at home close to the customers and companies can charge high prices because the demand for the new products is inelastic; 2) the maturity of products hence "export of the product to countries having the next-highest level of income as demand emerges in these developed countries; and 3) complete standardization of the product and its production process, which is no longer an exclusive possession of the innovating company hence FDI in developing or less developed countries with lower level of incomes, in order to save costs and explore possible cost advantages. Such hypothesis are evident today where we can find many well-known innovative products switching from the country of innovation, in the beginning acting as the net exporter, but later as net importer (for example Apple products).

As we analyze these stages in terms of cost advantages, FDI and human capital becomes important considerations especially when products and services reach the stage of maturity and standardization. In this case, FDI is considered to be a defensive move of companies in order to maintain competitive position against local and foreign investors.

\section{Conclusions}

This paper provided a review of theoretical and empirical literature of FDI in general, FDI types and theories and the relationship with human capital. The literature review reveals a diversity of thoughts regarding the nature of the relationship between FDI and human capital. Theory and empirical studies are inconclusive as per direct impacts of FDI in developed countries, but when it comes to transition 
Book of Proceedings

International Conference on Management, Business and Economics

and undeveloped economies, and Kosovo, there is more agreement on the positive effects of FDI in economic development and human capital.

In terms of types of FDI, the impact of FDI on human capital is more highlighted and studied in greenfield FDI type (especially the benefit of decreasing the unemployment in the host country) because this mode of investments usually creates new jobs and increases the productivity. Greenfield investments are a most welcomed foreign investment for host countries. The same can not be said for other two types of FDI: mergers \& acquisitions (M\&A) as well as joint ventures.

The examination of literature review, found that in most of the perfect market theories and hypothesis the role of human capital is less studied compared to imperfect market theories and hypotheses. In imperfect market theories, human capital is identified as an important determinant for capital flow and FDI attraction.

The importance of human capital in economic development is widely accepted nowadays. Human capital matters in attracting FDI inflows and can speed up the transfer of know-how from foreign investor to host country. FDI has a positive spillover effect and productivity of workforce in the host country. However, theory gives a significant influence of FDI on human capital, education, skill accumulation and other non-economic human development factors.

Bearing in mind that Kosovo is heavily populated with young people but faces high unemployment, it is very important to make strong bridges between the education system and FDI attraction. Kosovo needs a minimum of basic schooling for all adult workers to show that the country has a sound investment climate. In today's dynamic business environment, the linkage between the theory of schooling and practice at business is very central. The type of human capital necessary to attract FDI visibly depends on the type of FDI host countries seek.

\section{References}

1. Agarwal, P. J. (1980). Determinants of foreign investment: a survey. Weltwirtschaftliches Archive, 116, 739-77.

2. Bačić, K., Račić, D., \& Ahec-Šonje, A. (2004). The effects of FDI on recipient countries in Central and Eastern Europe. EIBA Conference (pp. 59-96). Ljubljana: EIBA.

3. Baldwin, R. E. (1995). The effects of trade and foreign direct investment on employment and relative wages. NBER Working Paper No. 5037, 1-48.

4. Barry, F., Görg, H., \& Strobl, E. (2001). Foreign direct investment and wages in domestic firms: productivity spillovers vs labour-market crowding out. Leverhulme Trust - Preliminary Draft, 121.

5. Berman, E., Bound, J., \& Griliches, Z. (1994). Changes in the demand for skilled labor within US manufacturing: evidence from annual survey of manufacturers. Quarterly Journal of Economics, 109, 367-398.

6. Blanchard, O. (1997). The economics of post-communist transition. Oxford: Claderon Press, Oxford. 
Foreign Direct Investment (FDI) Types and Theories: The Significance of Human Capital

7. Blomström, M., \& Kokko, A. (2002). FDI and human capital: a research agenda. $O E C D$ Working Paper No. 195, CD/DOC(2002)07, 1-34.

ณ. Blomström, M., \& Kokko, A. (2003). The economics of foreign direct investment incentives. Foreign Direct Investment in the Real and Financial Sector of Industrial Countries (pp. 1-25). Frankfurt: Bundesbank.

4. Bogun, L. (2009). Strategic fit for foreign direct investments in transition economies. International Journal of Business and Economics, 9(1), 93-99.

10. Bruno, R. (2006). Optimal speed of Transition with a shrinking labour force and under uncertainity. Economics of Transition, 14(1), 69-100.

11. Buckley, P. J., \& Casson, M. (1981). The Optimal Timing of a Foreign Direct Investment. Economic Journal, 91, 75-87.

12. Contessi, S., \& Weinberger, A. (2009). Foreign direct investment, productivity and country growth: an overview. Federal Reserve Bank of St. Louis Review, 61-78.

13. Costa, J., \& Teixeira, A. (2005). Universities as sources of knowledge for innovation. The case of technology intensive firms in Portugal. FEP Working Papers no. 181, 1-42.

14. Cushman, D. (1987). The effects of real wages and labour productivity on foreigm direct investment. Southern Economic Journal, 54, 174-185.

15. Denisia, V. (2010). Foreign direct investment theories: an overview of the main FDI theories . European Journal of Interdisciplinary Studies, 53-59.

16. Druska, V., Jeong, B., Kejak, M., \& Vinogradov, V. (2002). Assessing the problem of human capital mismatch in the transition economies. William Davidson Working Paper No. 467, 1-36.

17. Duczynski, P. (2001). On educational attainement in transition economies. Prague Economic Papers, 10(2), 163-173.

18. Dunning, J. H., \& Lundan, S. M. (2008). Multinational enterprises and the global economy. Massachusetts: Edward Elgar Publishing Limited.

14. Enache, I. T. (2010). Searching for human capital determinants of foreign direct investment inflows in the EU new member states. Annales Universitatis Apulensis Series Oeconomica, 12(1), 483 - 494.

20. Faeth, I. (2009). Determinants of foreign direct investment - a tale of nine theoretical models. Journal of Economic Surveys, 23(1), 165-196.

21. Hickman, D. C., \& Olney, W. W. (2011). Globalization and investment in human capital. Industrial and Labour Relations Review, 654-672.

22. Hoti, A. (2005). Assessing the problem of human capital mismatch in the transition economies: The case of Kosova. Prishtina: Institute for Development Research - RIINVEST.

23. Hufbauer, G. (1975). The multinational Corporation and Direct Investment in P.B Kenen (ed.). Cambridge: Cambridge, University Press.

24. IFC, W. B. (2015). Doing Business 2015. Washington: World Bank \& International Finance Corporation.

25. Katerina, L., John, P., \& Athanasios, V. (2004). Foreign direct investment and economic growth in transition economies. South Eastern Europe Journal of Economics, 97-110. 
Book of Proceedings

International Conference on Management, Business and Economics

26. KEC. (2011). Education for sustainable development Kosovo. Prishtina: Kosovo Education Centre - KEC.

27. Keeley, B. (2007). Human Capital - how what you know shapes your life. Organisation for Economic Co-operation and Development - OECD.

28. Kokko, A. (2006). The home country effects of FDI in developed economies. Stockholm School of Economics - Working Paper, 1-36.

24. Kucera, D. (2002). Core labour standards and foreign direct investment. International Labour Review, 141(1-2), 31 - 69.

3v. Majeed, M. T., \& Ahmad, E. (2008). Human capital development and FDI in developing countries. Journal of Economic Cooperation, 79-104.

31. Miyamoto, K. (2003). Human capital formation and foreign direct investment in develeping countries. OECD Working Paper No. 211-DEV/DOC(2003)09, 1-55.

32. Moosa, I. (2002). Foreign direct investment. Theory, evidence and practice. Hampshire - UK: Palgrave Publisher, Ltd. (formerly Macmillan Press, Ltd).

33. Moran, T. (2012). Foreign direct investment. London: John Wiley \& Sons.

34. Nasser, O. M. (2010). How does foreign direct investment affect economic growth? The role of local conditions. Latin American Business Review, 11, 111-139.

35. Nelson, R. R., \& Phelps, E. S. (1966). Investment in humans, technological diffusion, and economic growth. American Economic Review, 56, 69-75.

36. Popescu, R. G. (2011). The impact of foreign direct investments on labour productivity: a critical examination of results. The Romanian Economic Journal, 115-132.

37. Porter, M. (1990). The competitive advantage of nations. New York: The Free Press - A Division of Macmillan, Inc.

3.. Ragazzi, G. (1973). Theories of the determinants of foreign direct investment. IMF Staff Papers, 20, 471-498.

34. RIINVEST. (2012). Hulumtime dhe analiza për tërheqje të investimeve: praktikat e përdorura për tërheqjen e investimeve nga diaspora. Prishtina: Riinvest Institute.

40. Rizvanolli, A. (2010). The effect of human capital on foreign direct investment: a metaregression analysis. Riinvest Institute/AAB-Riinvest University conference "Activating Sources of Economic Growth in Kosovo" (pp. 1-30). Prishtina: Riinvest Institute for Development Research.

41. Spagat, M. (2006). Human capital and the future of transition economies. Journal of Comparative Economics, 44-56.

42. Talpos, I., \& Enache, C. (2010). Searching for human capital determinants of foreign direct investment inflows in the EU new member states. Annales Universitatis Series Oeconomica, 483-494.

43. Tudorescu, N., Zaharia, C., Zaharia, G. C., \& Zaharia, I. (2010). Human capital accumulation and long-run economic growth. Economics, Management, and Financial Markets, 5(4), 250255.

44. UNCTAD. (2012). World Investment Report 2012 - Towards a new generation of invesment policies. United Nations. 
Foreign Direct Investment (FDI) Types and Theories: The Significance of Human Capital

45. Vasyechko, O. (2012). A review of FDI theories: an application for transition economies. International Research Journal of Finance and Economics, 118-137.

46. Wang, M., \& Wong, S. (2011). FDI, education, and economic growth: quality matters. International Atlantic Economic Society, 103-115.

47. Zeqiri, N. (2010). The impact of FDI in transition economies: the experience of Hungary and Albania, and lessons for Kosova. Germany: Lambert Academic Publishing.

48. Zeqiri, N., Bytyqi, F., \& Likaj, J. (2011). The importance and Impact of Foreign Direct Investments in Transition Economies. International Journal of Advanced Economics and Business Management, 2, 58-72.

44. Zeqiri, N. (2013). The impact of human capital in attracting Foreign Direct Investments (FDI): Evidence from Republic of Kosovo. VDM Publishing Group, Scholars Press

50. Zhao, L. (1998). The impact of foreign direct investment on wages and employment. Oxford Economic Papers, 1-25.

5]. Žilinskè, A. (2010). Negative and positive effects of foreign direct investment. Economics and Management, 332-336. 